\title{
Krakowskie „Życie” jako forum prezentacji prądów ideowych i koncepcji światopoglądowych Młodej Polski (wybrane zagadnienia)
}

Krakowskie „Życie” (1897-1900) należy do najważniejszych czasopism Młodej Polski. W jego dziejach wyróżnia się zazwyczaj trzy fazy, związane z osobami kolejnych redaktorów: Ludwika Szczepańskiego (1897, nr 1-14; 1898, nr 1-22), Ignacego Sewera-Maciejowskiego i Artura Górskiego (1898, nr 23 36/37) oraz Stanisława Przybyszewskiego (1898, nr 38/39-50; 1899, nr 1-21/22; 1900, nr 1-2/3)', którzy odcisnęli indywidualne piętno na kształcie pisma w poszczególnych etapach jego powstawania ${ }^{2}$. Początkowo „Życie” - jako „Tygodnik ilustrowany, literacki, artystyczny, naukowy i społeczny" - miało ambicję zaznajamiania czytelników z najnowszymi prądami artystycznymi i intelektualnymi, „podnoszenia smaku publiczności”, a także kształtowania opinii publicznej w duchu, jak głosił Prospekt, idei postępowych i demokratycznych ${ }^{3}$. W ostatniej fazie istnienia „Życie” - jako „Czasopismo ilustrowane poświęcone

* Dr, mariajazownik@wp.pl, Akademia im. Jakuba z Paradyża w Gorzowie Wielkopolskim, Wydział Humanistyczny, Katedra Literatury, ul. Teatralna 25; 66-400 Gorzów Wielkopolski.

${ }^{1}$ Zmieniał się także podtytuł pisma. Początkowo brzmiał on: „Tygodnik ilustrowany literacki, artystyczny, naukowy i społeczny”; od numeru 23. w 1898: „Tygodnik ilustrowany literacki, artystyczny i społeczny”; od numeru 40./41. w 1898: „Tygodnik ilustrowany literacko-artystyczny, społeczny i naukowy”, od numeru 48. w 1898: „Tygodnik ilustrowany literacko-artystyczny”, od numeru 1. w 1899: „Dwutygodnik poświęcony literaturze i sztuce”, od numeru 13./14. w 1899: „Czasopismo ilustrowane poświęcone literaturze i sztuce” (wydawane co miesiąc w podwójnych numerach).

${ }^{2}$ Zob. m.in.: E. Boyé, U kolebki modernizmu. Estetyczne poglądy na łamach krakowskiego „Życia”, Krakowska Spółka Wydawnicza, Kraków 1922; A. Szymankiewicz, Z historii modernizmu polskiego (,Życie” warszawskie, „Życie” krakowskie, „Chimera”), „Przegląd Humanistyczny" 1923, t. 2, s. 29-55; J. Czachowska, ,Życie” 1897-1900, w: Obraz literatury polskiej XIX i XX wieku, seria V: Literatura okresu Młodej Polski, t. 1, red. K. Wyka, A. Hutnikiewicz, M. Puchalska, Państwowe Wydawnictwo Naukowe, Warszawa 1968, s. 233-244; A. Zyga, Program ideowo-artystyczny „Życia” za redakcji Ludwika Szczepańskiego, „Ruch Literacki” 1972, z. 3 (72), s. $135-152$.

3 „Życie” (Prospekt), Kraków-Lwów, wrzesień 1897 (60 tys. egz.). 
literaturze i sztuce” - stało się organem „ogólnoeuropejskiego buntu modernistycznego"4.

W dotychczasowej refleksji badawczej koncentrowano uwagę przede wszystkim na ogłaszanych na jego łamach manifestach literackich oraz eksponowano wkład pisma - widoczny zwłaszcza za redakcji Stanisława Przybyszewskiego w propagowanie idei sztuki autotelicznej; analizowano także zawartość pisma pod redakcją Ludwika Szczepańskiego 5 . W prezentowanym opracowaniu została podjęta próba przybliżenia periodyku jako miejsca toczonych u schyłku XIX wieku dyskusji ideologicznych i światopoglądowych, obejmujących takie między innymi zagadnienia, jak:

1) bankructwo ideałów XIX wieku (oraz związany z nim kryzys człowieka);

2) antynomia wartości rodzimych i uniwersalnych oraz wartości innych kultur;

3) relacje między tradycją a nowoczesnością;

4) zagrożenia związane $z$ rozwojem kultury masowej i upowszechnianiem się światopoglądu filisterskiego;

5) możliwości przezwyciężania światopoglądu dekadenckiego i artystowskiego ${ }^{6}$.

Repertuar istotnych problemów poruszanych na łamach „Życia” z pewnością dałoby się poszerzyć. Poprzestaniemy jednak na wymienionych kwestiach, uznając, że stanowią one zbiór na tyle reprezentatywny, by można było przedstawić pismo jako dokument epoki, ukazujący całą złożoność, czy nawet - w pewnym sensie - dialektykę polskiego modernizmu?.

Prezentowane uwagi i spostrzeżenia mają charakter rekonesansu, obejmują zatem tylko wybrane zagadnienia oraz do pewnego stopnia arbitralnie dobrane

${ }^{4}$ J. Czachowska, dz. cyt., s. 243. Zob. też B. Wojnowska, ,Życie” (1897-1900), w: Słownik literatury polskiej XX wieku, red. A. Brodzka, M. Puchalska, M. Semczuk, A. Sobolewska, E. Szary-Matywiecka, Zakład Narodowy im. Ossolińskich, Wrocław 1992, s. 1239-1244.

5 A. Zyga, Krakowskie „Życie” pod redakcja Ludwika Szczepańskiego (1897-1898), cz. I, „Kwartalnik Historii Prasy Polskiej” 1986, z. 3, s. 19-46; cz. II, „Kwartalnik Historii Prasy Polskiej” 1986, z. 4, s. 47-68; tenże, Literatura polska w „Życiu” pod redakcja Ludwika Szczepańskiego. W stulecie ukazania się pisma (1897-1997), „Rocznik Komisji Historycznoliterackiej PAN w Krakowie" 1994/1995, s. 107-123.

${ }^{6}$ Przedstawione zagadnienia nie mają charakteru rozłącznego, stanowią jedynie próbę uporządkowania różnorakich propozycji ideowych przedstawianych na łamach pisma.

${ }^{7}$ Kategoria dialektyki (rozumianej jako proces ścierania się, współistnienia i jednoczenia przeciwieństw) wydaje się bardzo poręczna w wyjaśnianiu procesów społeczno-kulturowych zachodzących na ziemiach polskich u schyłku XIX oraz na przełomie wieków XIX i XX. Ujęcia dialektyczne proponowali badacze oświecenia i pozytywizmu, m.in.: Th.W. Adorno, M. Horkheimer, Dialektyka oświecenia. Fragmenty filozoficzne, przeł. M. Lukasiewicz, Wydawnictwo Instytutu Filozofii i Socjologii PAN, Warszawa 1994; H. Markiewicz, Dialektyka pozytywizmu polskiego, w: tenże, Przekroje i zbliżenia dawne i nowe. Rozprawy i szkice z wiedzy o literaturze, Państwowy Instytut Wydawniczy, Warszawa 1976, s. 20-41; M. Gloger, Jak czytać pozytywizm. Rekonesans, „Poznańskie Studia Polonistyczne. Seria Literacka” 2000, t. VII: Czytanie pozytywizmu, s. 21-45. 
teksty. Zdecydowano się przede wszystkim na analizę tekstów dyskursywnych, przedstawiających idee i poglądy w sposób bezpośredni. Ponieważ publikacje tego rodzaju uległy znaczącej redukcji w trzeciej fazie istnienia pisma, zrozumiałe jest, że przedmiotem namysłu będą głównie wypowiedzi nacechowane ideologicznie i światopoglądowo opublikowane za redakcji Szczepańskiego i Górskiego ${ }^{8}$.

\section{Bankructwo ideałów XIX wieku (oraz związany z nim kryzys czlowieka)}

Edycja krakowskiego „Życia” zbiegła się w czasie z ugruntowaniem się w świadomości społecznej przeświadczenia, iż zakończył się pewien etap rozwoju kultury nowożytnej. Przeświadczeniu temu dał wyraz Artur Górski, który w cyklu polemiczno-programowym Młoda Polska stwierdził: „Żyjemy w czasie wielkich bankructw idei"’. Wskażmy główne rysy wchodzącej tu w rachubę sytuacji kryzysowej ${ }^{10}$.

Za najważniejszy wyznacznik wspomnianego przesilenia należy uznać kryzys światopoglądu, który nie sprowadzał się jedynie do „bankructwa” pozytywistycznej koncepcji rozwoju społecznego, lecz objął również inne doktryny światopoglądowe - i to zarówno religijne, jak też świeckie (filozoficzne). Destrukcji światopoglądu towarzyszyło przeświadczenie, iż wszelkie ideologie są jedynie narzędziami służącymi do zniewalania jednostek. Dodatkowo wraz ze skonstatowaniem relatywnego charakteru różnego rodzaju doktryn światopoglądowych uświadomiono sobie, że wchodzące w ich obręb systemy etyczne nie mają żadnych trwałych fundamentów oraz że nie istnieją żadne racje mogące usprawiedliwiać absolutyzowanie któregokolwiek z tych systemów ${ }^{11}$. U schyłku XIX wieku głoszono również tezę o kryzysie nauki (czy też - kryzysie prawdy) ${ }^{12}$, której

${ }^{8} \mathrm{~W}$ opracowaniu zrezygnowano z możliwości analizy koncepcji estetycznych oraz dyskusji literackich prezentowanych w „Życiu”, uznając, iż warto im poświęcić odrębny szkic; aczkolwiek w celu nakreślenia tendencji ideowych oraz światopoglądowych prezentowanych na łamach pisma wykorzystano niektóre spośród wypowiedzi krytycznoliterackich.

${ }^{9}$ Quasimodo [A. Górski], Młoda Polska. Fejleton nie posłany na konkurs „, Stowa Polskiego”, cz. IV, „Życie” 1898, nr 19, s. 217.

${ }^{10}$ Kwestię tę szeroko analizowali m.in.: K. Wyka, Młoda Polska, t. 1: Modernizm polski. Struktura i rozwój, wyd. 2, Wydawnictwo Literackie, Kraków 1987; T. Weiss, Przełom antypozytywistyczny $w$ Polsce $w$ latach 1880-1890 (przemiany postaw światopogladowych $i$ teorii artystycznych), Uniwersytet Jagielloński, Państwowe Wydawnictwo Naukowe, Kraków 1966; R. Zimand, „Dekadentyzm” warszawski, Państwowy Instytut Wydawniczy, Warszawa 1964; T. Walas, Ku otchtani (dekadentyzm w literaturze polskiej 1890-1905), Wydawnictwo Literackie, Kraków 1986.

${ }^{11} \mathrm{Na}$ ukształtowanie się tego przekonania szczególnie istotny wpływ mieli Ernest Renan i Friedrich Nietzsche.

12 Przyjmuje się, iż jako pierwszy u schyłku stulecia pogląd o bankructwie nauki wyartykułował w 1888 roku powieściopisarz i krytyk Paul Bourget. Zob. W. Tatarkiewicz, Renan i sceptycyzm 
zarzucano, iż poznaje tylko zjawiska, a nie ostateczną, metafizyczną istotę rzeczy. Spadek zaufania do nauki niewątpliwie w znacznym stopniu przyczynił się do destrukcji racjonalistycznego światopoglądu pozytywistycznego. Wraz z jego bankructwem przypieczętowane zostały procesy partykularyzacji i indywidualizacji, a co za tym idzie - relatywizacji systemów światopoglądowych ${ }^{13}$.

Nie dążąc do pełnej rejestracji licznych wypowiedzi autorów konstatujących na łamach „Życia” bankructwo dotychczasowych ideałów, warto przypomnieć kilka znamiennych opinii autora Młodej Polski. Jego deklaracje apolityczności oraz niechęci do partyjnych sporów i rozgrywek są wyrazem przeświadczenia o bankructwie ideologii. Przeświadczeniu temu towarzyszyło przekonanie o kryzysie wartości etycznych, uwarunkowanym w istotnej mierze zjawiskami znamiennymi dla galicyjskiego życia politycznego. W życiu tym bowiem wszystko, „co się dzieje w imię programu, to się dzieje jenseits von Gut und Böse”, dzięki czemu ,jak w Danii za Hamleta, «można być łotrem i mieć twarz uśmiechniętą$" "{ }^{14}$. Przekonanie krytyka, iż atmosfera galicyjskiego życia publicznego ma demoralizujący wpływ na jednostki, najpełniejszy swój wyraz znalazło w manifeście zatytułowanym Do młodzieży. Górski pisał:

Żyjemy w czasach, w których brak duchowi publicznemu jednolitości. Rozbiły się opinie stronnicze; sprzeczne mniemania krzyżują się w powietrzu, niezgodne prądy nurtują i zwierają się z sobą, czyny wprost przeciwne wywołują męczące i niezdrowe szamotanie się w głębi naszego społeczeństwa. Wytwarza się nie już zwykła walka zapatrywań politycznych, ale wprost zamęt w poczuciu moralnym, zachwianie znaczenia takich słów i pojęć, na które przecież dwu zdań być nie powinno, jak słowa i pojęcie kłamstwa, prawdy, uczciwości, patriotyzmu, chrześcijaństwa, postępu ${ }^{15}$.

Kryzys etyki przejawiał się także - jak twierdziła Izabela Moszczeńska w artykule Patriotyzm i moralność u nas - w postaci „patriotyzmu frazesów”"16. Według autorki, szkodliwość „hipokryzji patriotycznej” ujawniła się w nadużywaniu zarzutu braku patriotyzmu - ,najskuteczniejszej u nas broni do zabijania przeciwników”. Za pomocą „blagi patriotycznej” są zwalczani przeciwnicy polityczni, jak też „niewygodni” artyści. Pseudopatriotyzm bywa ponadto usprawiedliwieniem serwilizmu, szowinizmu, nietolerancji i poczucia wyższości ${ }^{17}$.

w pozytywizmie, w: tenże, Historia filozofii, Państwowe Wydawnictwo Naukowe, Warszawa 1981, t. 3 , s. 130.

${ }^{13}$ Wykorzystuję tu ustalenia zawarte w mojej pracy Krytyka literacka Artura Górskiego 1890-1918, Księgarnia Akademicka, Zielona Góra 2012, s. 64-66.

${ }^{14}$ Quasimodo [A. Górski], Młoda Polska ..., „Życie” 1898, nr 24, s. 278.

15 [A. Górski], Do młodzieży, „Życie” 1897, nr 12, s. 1. Jest to artykuł wstępny, zgodnie z informacją na s. 12 wskazanego numeru napisany przez Górskiego w imieniu redakcji „Życia”.

${ }^{16}$ I. Moszczeńska, Patriotyzm i moralność u nas, „Życie” 1898, nr 15, s. 170.

${ }^{17}$ Tamże, „Życie” 1898, nr 16, s. 184. 
W przekonaniu publicystki istnieje ścisły związek między obłudą patriotyczną i obłudą moralną:

Ze źle pojętego patriotyzmu tworzymy cło ochronne dla naszych tandetnych moralnych wyrobów, podnosimy sztucznie wartość drobniutkich lub fałszowanych cnót - osłaniamy miejscowe błędy i występki i systematycznie przyczyniamy się do obniżenia poziomu moralnego $\mathrm{w}$ narodzie ${ }^{18}$.

Obok zasygnalizowanych wypowiedzi ujmujących zagadnienia etyczne w kontekście galicyjskiej polityki, „Życie” opublikowało również rozważania Cezarego Jellenty zatytułowane Proces moralny, poświęcone omówieniu głównych koncepcji etycznych powstałych w XIX wieku: Wilhelma Wundta, Herberta Spencera, Johna Stuarta Milla, Alfreda Fouillée'go, a w szczególności poglądów przedstawiciela filozofii życia, Jeana-Marie Guyau. Jellenta zauważył, że większość współczesnych koncepcji etycznych łączy „przekonanie o zmienności i względności nakazów moralnych" ${ }^{19}$, a moralność jest w nich równoznaczna z historycznie zmienną tresurą społeczną. Autor, solidaryzując się z poglądami Guyau, twierdzi, że istota moralności nie polega, jak się zazwyczaj bezrefleksyjnie sądzi, na wyuczonym wykonywaniu zalecanych społecznie przepisów, lecz jest związana z procesami moralnymi zachodzącymi w ludzkiej duszy ${ }^{20}$.

Jak wynika z wcześniejszych uwag, kryzys ideologii i etyki publicyści ,Życia" traktowali jako przejaw szerszego zjawiska, a mianowicie kryzysu systemów światopoglądowych. Na przykład Górski czy Miciński konstatowali „niewystarczalność" pozytywistycznego scjentyzmu i nawoływali do powrotu do Mickiewicza-mistyka „po zgubiony wątek” filozofii narodowej ${ }^{21}$.

Bankructwo ideałów ściśle wiąże się z kryzysem człowieczeństwa. Przejawia się on nie tylko w podważeniu znaczenia dotychczasowych kategorii etycznych, lecz także w poczuciu wyczerpania kultury. Według Zofii Daszyńskiej, człowiek końca wieku XIX, czyli - jak go określiła publicystka - „człowiek nowoczesny”, zauważa, że kreowanie zawsze jest do pewnego stopnia powielaniem (motywów, konwencji, postaw artystycznych). Świadomość tego stanu rzeczy wpływa niszcząco na jego psychikę - degraduje wolę oraz uniemożliwia doznawanie głębokich przeżyćc ${ }^{22}$. Nowym źródłem energii życiowej - w miejsce kultury - stała

18 Tamże, „Życie” 1898, nr 17, s. 194.

${ }^{19}$ C. Jellenta, Proces moralny, „Życie” 1898, nr 44, s. 578.

20 Tamże, „Życie” 1898, nr 45, s. 600.

${ }^{21}$ Quasimodo [A. Górski], Młoda Polska ..., cz. VI, „Życie” 1898, nr 25, s. 299; T. Miciński, O spuściźnie duchowej, „Życie”1899, nr 7, s. 122.

22 Z. Daszyńska, Z tajników duszy współczesnej, ,Życie” 1898, nr 13, s. 147. Artykuł był opatrzony mottem w postaci pierwszej zwrotki wiersza Kazimierza Przerwy-Tetmajera o incipicie „Melancholia, tęsknota, smutek, zniechęcenie...” (z tomu Poezje. Seria II z 1894 r., z cyklu Zamyślenia). 
się cywilizacja wielkomiejska. Daszyńska pisze: „Żywiołem nowoczesnego człowieka [jest - M.J.] tłum i chaos, który pobudza jego nerwy, przyspiesza tętno pulsu, ożywia myślenie"23. Niestety, postęp cywilizacyjny wymusza jednostronny, wyłącznie intelektualny rozwój: „Życie umysłowe, rozszerzanie widnokręgu myśli i pogłębianie wiedzy jest stałą życiową funkcją nowoczesnych ludzi"24. Sfera uczuć natomiast staje się „pierwiastkiem konserwatywnym”. Rozdźwięk między intelektem a uczuciem - podkreśla Daszyńska - to „nieszczęście nowoczesnych ludzi" ${ }^{25}$. Publicystka zauważa też, że między nowoczesnym mężczyzną (,produktem schyłkowej naszej kultury”), którego wyróżnia krytyczny intelekt, a współczesną kobietą, która „zachowuje dawną duszę naiwną”, występuje silniejszy niż kiedykolwiek antagonizm ${ }^{26}$. Konflikt płci, według Daszyńskiej, to swoiste signum temporis, znak świata współczesnego przepełnionego całym szeregiem konfliktów.

Publicyści „Życia” wskazują inne jeszcze - oprócz społecznych i kulturowych - powody zachwiania pozycji człowieka. Na ziemiach polskich należą do nich upokarzające warunki egzystencji w niewoli, które - jak pisze warszawski korespondent pisma Bolesław Lutomski - ukształtowały polski typ narodowy. Wstrząsy polityczne oraz ograniczone możliwości inicjatywy spowodowały, że Polska „stała się muzeum patologicznym chorób duchowych i chorób społecznych, i to zarówno w wyższych, jak i niższych warstwach. [...] Specjaliści chorób nerwowych wyznają, że żaden kraj nie dostarcza im pacjentów z tak dręczącymi objawami, jak Polska”27. Autor podkreśla: „Leopardi powinien się był urodzić w Polsce dziewiętnastego stulecia. Tutaj sprzysięgało się wszystko dla usprawiedliwienia jego posępnej religii"28.

Również Artur Górski uwzględniał kontekst polityczny w swoich diagnozach kryzysu współczesności. Nade wszystko zwracał uwagę na negatywne skutki wyplenienia ducha narodowego w szkołach, ujawniające się w degeneracji części młodzieży, skłonnej do przyjmowania postaw dekadenckich. „Upowszechnia się - stwierdza publicysta - typ młodzieńca zobojętniałego, który nic nie kocha, ma skłonność do cynizmu, nierzadko kończy samobójczo, w przekonaniach jest

${ }^{23}$ Tamże, s. 146.

24 Tamże, „Życie” 1898, nr 14, s. 159.

${ }^{25}$ Tamże. Zob. też M. Stala, Człowiek z właściwościami (W kręgu antropologicznej problematyki Młodej Polski), w: Stulecie Młodej Polski. Studia, red. M. Podraza-Kwiatkowska, Universitas, Kraków 1995, s. 135-152.

${ }^{26}$ Z. Daszyńska, Z tajników duszy wspótczesnej, „Życie” 1898, nr 14, s. 160. O publicystyce Daszyńskiej na łamach „Życia” pisałam w artykule Kobiety autorki w krakowskim „Życiu”, w: Wspótczesny i dawny obraz kobiety w języku i literaturze, red. L. Mariak, J. Rychter, Volumina. pl Daniel Krzanowski, Szczecin 2015, s. 87-106.

${ }^{27}$ B. Lutomski, Z psychologii narodowej, „Życie” 1897, nr 4, s. 2.

${ }^{28}$ Tamże. 
indyferentny, co najwięcej zdobędzie się na antysemityzm" ${ }^{29}$. W podobnym tonie Górski wypowiadał się w cyklu Młoda Polska, zarzucając zwolennikom realizmu politycznego, iż ich swoista pedagogia służy wychowaniu obojętnych na sprawy narodowe karierowiczów i dekadentów ${ }^{30}$.

\section{Antynomia wartości rodzimych i uniwersalnych oraz wartości innych kultur}

Z uwagi na uwarunkowania historyczne wokół wskazanej antynomii ogniskowały się prowadzone wówczas spory i dyskusje ideowe. Dla Polski od ponad stu lat pozbawionej bytu państwowego niezmiernie istotne były pytania o warunki zachowania tożsamości narodowej oraz wartości gwarantujące zachowanie ciągłości kultury. Pytania te stawiali także publicyści ,Życia”, zwłaszcza wówczas, gdy - oskarżeni o hołdowanie prądom zachodnim - w toku dyskusji na temat sztuki narodowej zmuszeni zostali do zajęcia stanowiska. Sprawy te już wielokrotnie referowano ${ }^{31}$, dlatego jedynie przypomnijmy, że w finale dyskusji Górski w imieniu pokolenia deklarował przywiązanie do narodowych tradycji, a jednocześnie akcentował konieczność rozwijania kultury narodowej w ścisłym związku z dorobkiem cywilizacyjnym i kulturowym Europy Zachodniej ${ }^{32}$. Nie widział też sprzeczności między wartościami narodowymi a uniwersalnymi; uznawał bowiem, że najdojrzalsze wytwory artystyczne wyrastają jednocześnie z głębin ducha narodowego oraz powszechnych i odwiecznych doświadczeń ludzkości. W przekonaniu redaktorów pisma taki charakter mają przede wszystkim dzieła polskich wieszczów narodowych. Wykorzystując okoliczności rocznicowe, a zwłaszcza setną rocznicę urodzin Mickiewicza oraz pięćdziesiątą rocznicę śmierci Słowackiego, Szczepański i Górski prezentowali obfity materiał świadczący o istnieniu w kręgu pisma kultu wieszczów ${ }^{33}$.

${ }^{29}$ A.G. [Artur Górski], Młodzież a pedagodzy, „Życie” 1898, nr 11, s. 130-131.

${ }^{30}$ Quasimodo [A. Górski], Młoda Polska ..., cz. II, „Życie”1898, nr 16, s. 181.

${ }^{31}$ Zob. np.: K. Wyka, Programy, syntezy i polemiki literackie okresu, w: tenże, Młoda Polska, t. 2: Szkice z problematyki epoki, wyd. 2, Wydawnictwo Literackie, Kraków 1987, s. 93-99; M. Podraza-Kwiatkowska, Wstę, w: Programy i dyskusje literackie okresu Młodej Polski, oprac. M. Podraza-Kwiatkowska, wyd. 3. przejrz. i uzup., Zakład Narodowy im. Ossolińskich, Wrocław 2000, BN I 212, s. VIII-XX; A. Kieżuń, Drogi własne. O twórczości młodopolskiej Artura Górskiego, Wydawnictwo Uniwersytetu w Białymstoku, Białystok 2006, s. 84-120; M. Jazownik, Krytyka..., s. 70-113, 122-134, 204-213.

${ }^{32}$ Quasimodo [A. Górski], Młoda Polska..., cz. VI, „Życie”1898, nr 25, s. 299.

${ }^{33} \mathrm{Na}$ temat recepcji romantyzmu w kręgu krakowskiego „Życia” pisałam m.in. w artykułach: Krakowskie „Życie” wobec setnej rocznicy urodzin Adama Mickiewicza, w: Adam Mickiewicz wkontekstach kulturowych dawnychi wspótczesnych, red. I. Jokiel, M. Burzka-Janik, Wydawnictwo 
Zmierzając z kolei do przybliżenia sposobu rozstrzygania kwestii relacji wartości rodzimych i obcych, warto zaznaczyć, że „Życie” było pismem galicyjskim $^{34}$. Główną grupę jego odbiorców stanowili mieszkańcy Galicji, ówczesnej prowincji Austro-Węgier, zamieszkałej przede wszystkim przez Polaków, Żydów i Rusinów. Wielonarodowość i wielokulturowość krainy były jej bogactwem, ale bywały też źródłem konfliktów, rejestrowanych za redakcji Szczepanowskiego i Górskiego. Ściśle rzecz biorąc, chodziło zwłaszcza o relacje polsko-rusińskie oraz polsko-żydowskie. Należy podkreślić, że redaktorzy „Życia”, nieuchylający się od nagłaśniania i piętnowania przejawów nacjonalizmu i antysemityzmu, wykazali się znaczną odwagą, a także obiektywizmem.

Jeśli chodzi o stosunki polsko-rusińskie, w owym czasie rzucił na nie cień artykuł Iwana Franki o Mickiewiczu Poeta zdrady, opublikowany w wiedeńskiej gazecie „Die Zeit” w 1897 roku $^{35}$. Paszkwil, ogłoszony podczas przygotowań do obchodów stuletniej rocznicy urodzin Mickiewicza, wywołał falę krytyki i oburzenia Polaków ${ }^{36}$. Napastliwy sposób pisania o polskim wieszczu narodowym przejęli inni autorzy. Obszernie relacjonował ten fakt Wilhelm Feldman, lwowski korespondent „Życia” ${ }^{37}$. Informował, że 22 maja 1898 roku, dokładnie podczas obchodów Dnia Mickiewiczowskiego we Lwowie, w pismach „Prapor” i „Diło” ukazał się artykuł, którego autor przestrzegał przed możliwością zaszczepienia Rusinom takich ideałów - rzekomo obecnych w twórczości Mickiewicza - jak: „kult szału, bezbożność dochodząca do bluźnienia Bogu, apoteoza żydostwa i dyktowanej patriotyzmem zdrady, schlebianie bezmyślności i zepsuciu pewnych stanów i zupełne ignorowanie cierpień szerokich warstw pracującego ludu"38.

Uniwersytetu Opolskiego, Opole 2012, s. 200-225; Portret Juliusza Stowackiego na łamach krakowskiego „Życia”. Przyczynek do badań nad stylami lektury wieszcza, w: Współczesne problemy badań nad recepcją oraz oddziaływaniem utworów literackich, red. L. Jazownik, Księgarnia Akademicka, Zielona Góra 2013, s. 149-169; Fryderyk Chopin w eseistyce Stanistawa Przybyszewskiego, w: Słowo, dźwięk, obraz, red. E. Skorupska-Raczyńska, J. Rutkowska, Wydawnictwo Naukowe PWSZ im. Jakuba z Paradyża, Gorzów Wielkopolski 2016, s. 37-59.

34 „Życie” wydawane było w Krakowie, ale do numeru 22. z 1898 r. redaktorzy wskazywali na stronie tytułowej pisma - podobnie jak w Prospekcie w 1897 r. - także Lwów jako drugie centrum nowej sztuki.

${ }^{35}$ I. Franko, Ein Dichter des Verrathes, „Die Zeit” 1897, nr 136, s. 86-89.

${ }^{36}$ Zob. Cz. Partacz, Od Badeniego do Potockiego. Stosunki polsko-ukraińskie w Galicji w latach 1888-1908, Wydawnictwo Adam Marszałek, Toruń 1997, s. 67.

37 [W. Feldman] $\Delta$, Listy lwowskie. Lwów, dnia 25. V. 1898, „Życie” 1898, nr 22, s. 261. Korespondencja Feldmana była publikowana w ciągu jednego roku (1897, nr 9 z 20 listopada - 1898, $\mathrm{nr} 45 \mathrm{z} 26$ listopada), zazwyczaj w tygodniowym odstępie; pod koniec także pt. List lwowski, Ze Lwowa, Teatr lwowski, Lwów. Zob. M. Jazownik, Obraz Lwowa w korespondencji Wilhelma Feldmana ukazujacej się na tamach krakowskiego „Życia”, w: Dziedzictwo kulturowe regionu pogranicza, t. 6, red. E. Skorupska-Raczyńska, J. Rutkowska, Wydawnictwo Naukowe Państwowej Wyższej Szkoły Zawodowej im. Jakuba z Paradyża, Gorzów Wielkopolski 2015, s. 37-61.

${ }^{38}$ [W. Feldman] $\Delta$, dz. cyt. 


\section{Komentując wspomniany artykuł, Feldman stwierdza:}

Co by to był za krzyk, gdyby ktoś z nas śmiał pisać o autorze Hajdamaków, Szewczence, w taki sposób, w jaki jego następcy piszą o Adamie! Żaden hakatysta, żaden Rosjanin, żaden Europejczyk nie odnosi się w ten sposób do tego, co nazywamy ideałem naszego ducha, jak owi „bracia” ${ }^{\prime 3}$.

W świetle wskazanych okoliczności późniejsza prezentacja na łamach krakowskiego pisma sylwetki młodego ukraińskiego pisarza Wasyla Stefanyka oraz publikacja jego nowelistyki w przekładzie Wacława Moraczewskiego powinny być odebrane jako świadectwo braku uprzedzeń narodowych w zespole redakcyjnym ${ }^{40}$.

Z kolei o propagowanych na łamach „Życia” poglądach na kwestię relacji polsko-żydowskich najlepiej świadczą opinie środowisk konserwatywno-klerykalnych, od początku atakujących pismo, głównie w antysemickim „Głosie Narodu". Dziennik ten już nowo powstałemu periodykowi zarzucał filosemityzm, między innymi w związku z wystawieniem sztuki Małka Szwarcenkopf, autorstwa współpracującej z „Życiem” Gabrieli Zapolskiej, a także wytykał szerzenie poglądów niezgodnych z tradycyjną moralnością ${ }^{41}$. Środowisko dziennikarskie "Głosu Narodu" zobrazowała Zapolska w powieści Antysemitnik, drukowanej w odcinkach w pierwszej i drugiej fazie istnienia pisma.

„Życie” komentowało również ogłoszenie 27 czerwca 1898 roku przez rząd w Wiedniu stanu wyjątkowego na obszarze Galicji Zachodniej w celu zatrzymania rozruchów antyżydowskich ${ }^{42}$. Według Feldmana jedną z istotnych przyczyn zamieszek było to, że część niepiśmiennej ludności uwierzyła prowokatorom i agitatorom, iż sam „,cesarz pozwolił bić i plądrować” ${ }^{\text {"3 }}$. W tej sytuacji - pisał felietonista - należy nieść oświatę i krzewić świadomość narodową wśród ludu. Warto przy tym zauważyć, że Feldman nie był apologetą środowiska, z którego się wywodził.

${ }^{39}$ Tamże.

${ }^{40}$ W. Moraczewski, Wasyl Stefanyk, „Życie” 1899, nr 10, s. 195-196. Na łamach „Życia” w 1899 r. ukazały się następujące utwory Stefanyka: Kasia, Nowina (nr 10), Majster, Rodzina Bartka (nr 13/14), W rekruty, Aniol (nr 19/20).

${ }^{41}$ Zob. np.: Redakcja „Życia”, „Glosowi Narodu” na dalsza droge, „Życie” 1897, nr 3, s. 12; Audax [Kazimierz Ehrenberg], Uwagi, „Głos Narodu” 1898, nr 248, s. 6; tenże, Uwagi, „Głos Narodu" 1898, nr 253, s. 5.

42 [W. Feldman] $\Delta$, List lwowski. Lwów, 29. VI, „Życie” 1898, nr 26, s. 324; [A. Górski] ***, Stan wyjątkowy, „Życie” 1898, nr 34, s. 441-442. Stan wyjątkowy umożliwił władzom podjęcie działań mających na celu zahamowanie rozwoju ruchu socjalistycznego, m.in. przez zamknięcie niektórych czasopism oraz wprowadzenie zakazu zgromadzeń. Społeczne i polityczne tło zaburzeń oraz ich przebieg naświetlił M. Soboń, Pogromy w Galicji w 1898 roku i ich społeczne konsekwencje, w: tenże, Polacy wobec Żydów w Galicji doby autonomicznej w latach 1868-1914, Wydawnictwo Verso, Kraków 2011, s. 238-270.

${ }^{43}$ [W. Feldman] $\Delta$, List lwowski. Lwów, dnia 29. VI, „Życie” 1898, nr 26, s. 324. 
Jako zwolennik idei asymilacji Żydów, piętnował egoizm elit żydowskich, obojętnych na los warstw niższych: „Czas w ogóle najwyższy, aby inteligencja żydowska, tak sobkowski prowadząca żywot, poczuła się także do jakichś obowiązków społecznych!’4 . Nie przemilczał również szowinistycznych postaw wśród Żydów:

Młodzież pochodzenia żydowskiego tutejsza, stoi, przeciętnie biorąc, na poziomie niższym niż rdzennie polska; niczym nie zaznacza śladu swej działalności dla kraju [...]. Rezonuje tylko i wyrabia w sobie specjalny patriotyzm żydowski, natury czysto negatywnej, wyradzający się najczęściej w szowinizm ${ }^{45}$.

Redaktorzy „Życia” nie zasklepiali się w kręgu spraw galicyjskich. Wspierali, na przykład, dążenia emancypacyjne Czechów. Pismo nagłośniło między innymi sprawę listu otwartego profesora Oswalda Balzera do Theodora Mommsena, niemieckiego historyka, zwolennika Hakaty i polityki Ottona Bismarcka. Mommsen w głośnej odezwie opublikowanej w czasie walki Czechów o prawo używania języka czeskiego w urzędach nazwał Słowian ,,apostołami barbarzyństwa", niszczącymi dokonania Niemców w Europie Środkowo-Wschodniej. Polski historyk, autor monumentalnej Genealogii Piastów (1895), w skierowanym do Mommsena liście domagał się poszanowania dla kultury słowiańskiej ${ }^{46}$. Ze strony czeskiej wystąpił między innymi poeta Antonín Sova. Jego odpowiedzią na nacjonalistyczny paszkwil był opublikowany na łamach „Życia” wiersz Teodorowi Mommsenowi ${ }^{47}$.

Redakcja omawianego periodyku obszernie informowała również o wytoczeniu Emilowi Zoli kolejnego procesu w związku z jego zaangażowaniem w tak zwaną sprawę Alfreda Dreyfusa, francuskiego oficera pochodzenia żydowskiego, niesłusznie oskarżonego o zdradę. Warto dodać, że redakcja „Życia” jako jedna z nielicznych na ziemiach polskich zamieściła sporo informacji o wspomnianej sprawie i z wielką przychylnością pisała o postawie Zoli, wyrażonej przez niego w liście otwartym skierowanym do prezydenta Republiki Francuskiej, zatytułowanym J'Accuse...! (Oskarżam...!; „L'Aurore”, 13 stycznia 1898) ${ }^{48}$. Wystosowała też do Zoli specjalny telegram „w dowód uznania jego odwagi i szlachetnego, prawdziwie humanitarnego wystąpienia w sprawie Dreyfusa"49.

\footnotetext{
${ }^{44}$ Tenże, Listy lwowskie. Lwów, dnia 4. V. 1898, „Życie” 1898, nr 19, s. 223.

45 Tenże, Listy lwowskie. Lwów, dnia 27. IV. 1898, „Życie” 1898, nr 18, s. 213.

${ }^{46}$ Tenże, Listy lwowskie II. Lwów, dnia 25 listopada, „Życie” 1897, nr 10, s. 7. Zwolennikiem równouprawnienia w Czechach języków czeskiego i niemieckiego był premier Kazimierz Badeni (1846-1909). Badeni został zdymisjonowany przez cesarza 28 listopada 1897 r. po zamieszkach w Wiedniu zorganizowanych przez nacjonalistów niemieckich nieakceptujących jego rozporządzenia językowego.

${ }^{47}$ A. Sova, Teodorowi Mommsenowi, przeł. M. Szukiewicz, „Życie” 1897, nr 12, s. 2.

${ }^{48}$ Zob. np. [Redakcja], J'Accuse!, „Życie” 1898, nr 4, s. 37.

${ }^{49}$ Kronika, ,Życie” 1898, nr 4, s. 46.
} 
Nieco inaczej wygląda relacja miedzy wartościami swojskimi i obcymi w okresie redakcji Przybyszewskiego. Zmieniwszy profil pisma, pisarz zrezygnował $\mathrm{z}$ informowania o aktualnych sprawach społecznych czy politycznych i zwrócił się ku tematyce uniwersalnej, propagując poprzez teksty literackie polskich i europejskich przedstawicieli modernizmu takie tematy, jak śmierć, miłość, zło, cierpienie, szaleństwo. Znamienne, że po objęciu pisma nie kontynuował prowadzonych z dużym rozmachem działań poprzedniej redakcji bardzo zaangażowanej w upamiętnienie 100. rocznicy urodzin Mickiewicza. Niebawem jednak nawiązał do tradycji romantycznej w dwóch preekpresjonistycznych esejach: Apostrofa do Króla Ducha, poświęconym Słowackiemu ${ }^{50}$, oraz Ku czci mistrza, dedykowanym Chopinowi ${ }^{51}$.

Zamykając ten fragment rozważań, należy podkreślić, że najbardziej o otwartości wszystkich redaktorów „Życia”, a w szczególności Przybyszewskiego, na inne kultury świadczy liczba autorów obcych, zarówno zachodnich, jak też z kręgu Słowiańszczyzny, których dzieła były prezentowane i komentowane na łamach pisma. Jest to tak obszerne zagadnienie, obejmujące recepcję europejskiej czy nawet światowej literatury, sztuki i filozofii, że zasługuje na odrębną rozpra$w_{e^{52}}$. Jedynie tytułem przykładu wskażmy choćby najgłośniejszych podówczas myślicieli i teoretyków sztuki, których idee upowszechniano w krakowskim periodyku; byli to m.in: Friedrich Nietzsche ${ }^{53}$, Søren Kierkegaard ${ }^{54}$, Max Stirner ${ }^{55}$, Lew Tołstoj ${ }^{56}$, Oscar Wilde ${ }^{57}$.

${ }^{50}$ S. Przybyszewski, Apostrofa do Króla Ducha. U progu nowego stulecia, „Życie” 1900, nr 1, s. $3-5$.

${ }^{51}$ Tenże, Ku czci mistrza, „Życie” 1899, nr 19/20, s. 351-356.

52 Zob. G.P. Bąbiak, Bibliografia zawartości „Życia” warszawskiego i krakowskiego, „Strumienia” oraz „Chimery”, Wydział Polonistyki UW, Warszawa 2000, s. 41-94.

${ }^{53}$ W.F. [W. Feldman], Nietzsche, „Życie” 1898, nr 21, s. 244-245; F. Nietzsche, Pieśń nocy, „Życie” 1898, nr 36/37, s. 488; tenże, Przedmowa Zarathustry, „Życie” 1898, nr 45, 622, 625; nr 48, s. 639-640, 643; tenże, Z „Also Sprach Zarathustra”, „Życie” 1899, nr 1, s. 17-18; tenże, Jeszcze raz po wszystka wieczność, przeł. J. Żuławski, „Życie” 1900, nr 1, s. 26.

${ }^{54}$ S. Kierkegaard, Dziennik uwodziciela, ,Życie” 1899, nr 8, s. 152-155, nr 9, s. 174-175, nr 10, s. 201 , nr 11 , s. $219-221$, nr $13 / 14$, s. $261-269$, nr $15 / 16$, s. $294,297-300$, nr $17 / 18$, s. 339-348, nr 19/20, s. 373-378, nr 21/22, s. 404-410.

${ }^{55}$ A. Górski, Jedyny, „Życie” 1899, nr 8, s. 146, 149-151, nr 9, s. 166, 169-173.

${ }^{56}$ A. Potocki, Totstoj, „Życie” 1898, nr 34, s. 443; L. Tołstoj, Co to jest sztuka?, przeł. A. Potocki, „Życie” 1898, nr 35, s. 457-459; nr 36/37, s. 476-477.

${ }^{57}$ O. Wilde, Krytyk jako artysta, przeł. R.W., ,Życie” 1898, nr 7, s. 76-77, nr 8, s. 87-88, nr 10, s. $113-114$, nr 12 , s. 138 , nr 13, s. 150-151, nr 16, s. 185-186, nr 17, s. 197, nr 20, s. 233-234. 


\section{Relacje między tradycją a nowoczesnością}

Relacje te ujawniają się w „Życiu” między innymi w wypowiedziach zestawiających polską kulturę rustykalną z nowoczesną kulturą miejską. Choć pierwsi redaktorzy pisma deklarowali się jako zwolennicy postępu społecznego i cywilizacyjnego, dość zresztą ogólnikowo ujmowanego, rychło wyłonił się w piśmie wyraźny nurt ludomański, reprezentowany przez Włodzimierza Tetmajera jako autora artykułu Chłop polski na uroczystości Mickiewiczowskiej58, a także przez Artura Górskiego, autora studium Włodzimierz Tetmajer ${ }^{59}$, poświęconego malarstwu oraz ideologii artysty. Obaj publicyści w duszy ludu odnajdywali źródło siły i trwałości rodzimej kultury. W wypowiedzi Górskiego, postulującego związek sztuki z ziemią, życiem i przyrodą, wyraźnie pobrzmiewają poglądy Johna Ruskina:

Pojmując sztukę w oderwaniu od życia, oddalamy się od przyrody, która je zawsze łączy i pomnażamy brzydotę ziemi. Pomnażamy ją w naszych miastach smrodliwych $\mathrm{i}$ brudnych, pomnażamy w ubiorze niedorzecznym i niezdrowym, pomnażamy w ciałach tracących kształt pierwotny i harmonię $[\ldots]^{60}$.

Poza wypowiedziami Tetmajera, Górskiego oraz wspomnianym wcześniej artykułem Daszyńskiej problematyka nowoczesnego miasta nie była przedmiotem specjalnego namysłu autorów pisma. Na uwagę zasługuje natomiast dokonane przez Kazimierza Kelles-Krauza omówienie futurystycznej wizji ludzkości stworzonej przez Gabriela de Tarde'a ${ }^{61}$. Tekst francuskiego socjologa, badacza psychologii tłumu, zatytułowany Urywek historii przyszłości (Fragment d'histoire future; 1896), komentator potraktował jako formę krytyki ideałów społecznych teraźniejszości. Według niego, Tarde ukazał doskonałe wypełnienie mitu cywilizacyjnego postępu, polegającego na powstaniu niewielkiej grupy ludzkości, poddanej całkowitej (auto)kontroli, samowystarczalnej, pozbawionej trosk materialnych, zupełnie niezależnej od twórczej i zarazem nieprzewidywalnej natury; zbiorowości homogenicznej, realizującej „,wzniosły ideał ludzkości: jak najmniej pracy utylitarnej, jak najwięcej pracy estetycznej”"62. Jak pisze publicysta, Tarde „formułuje tu w inny sposób «prawo do próżniactwa» Lafargue'a"63.

${ }^{58}$ W. Tetmajer, Chłop polski na uroczystości Mickiewiczowskiej, „Życie” 1898, nr 26, s. 313-316.

${ }^{59}$ A. Górski, Włodzimierz Tetmajer (,Żeńcy”, „Racławice”, „Kantyczki”), „Życie” 1899, nr $13 / 14$, s. $244-245$.

${ }^{60}$ Tamże, s. 244. Na temat młodopolskiej recepcji poglądów Johna Ruskina zob. B. Wojnowska, ,,Ruskinizm” w Młodej Polsce, „Studia Estetyczne” 1976, s. 259-281.

${ }^{61}$ K. Kelles-Krauz, Podziemna przyszłość ludzkości, „Życie” 1897, nr 9, s. 5-6, nr 10, s. 4-5, nr 11, s. 5-6, nr 12, s. 5-7, nr 13, s. 5-7, nr 14, s. 6-8; 1898, nr 1, s. 5-7, nr 2, s. 15-17.

62 Tamże, „Życie” 1897, nr 13, s. 6.

${ }^{63}$ Autor ma na myśli pracę francuskiego filozofa marksistowskiego Paula Lafargue'a Prawo do lenistwa (Le droit à la paresse, 1883). 
Dziś wizja de Tarde'a bywa interpretowana jako projekt cywilizacji wielkomiejskiej w pełni zaspokajającej potrzeby materialne ludzi mogących się skoncentrować wyłącznie na aktywności twórczej ${ }^{64}$. Warto zaznaczyć, że kilkuodcinkowy cykl o podziemnym życiu ludzkości przyszłości nie spotkał się w piśmie z żadnym oddźwiękiem.

$\mathrm{Na}$ łamach pisma konfrontowano również tradycyjne wzorce obyczajowe z tymi, które proponował prąd feministyczny. Należy podkreślić, że pierwsi redaktorzy byli zwolennikami idei emancypacji kobiet, zamieszczali liczne materiały informacyjne o lwowskim i krakowskim ruchu kobiecym. Problematykę kobiecą podejmowali w „Życiu” zarówno publicyści, jak też publicystki. Tym ostatnim należy się szczególna uwaga. Współpracowały bowiem z "Życiem” autorki nietuzinkowe - działaczki społeczne i oświatowe, uczone, publicystki, pisarki, tłumaczki ${ }^{65}$. Krakowskie pismo nie było pod tym względem jakimś wyjątkiem. Dynamizujący się w okresie popowstaniowym ruch emancypacyjny, na ziemiach polskich silnie zdeterminowany przez okoliczności polityczne i ekonomiczne, przyczynił się do tego, że kobiety coraz częściej przyjmowały role do tej pory zastrzeżone dla mężczyzn i coraz głośniej upominały się o prawo do wykształcenia i rozwoju zawodowego.

Za czasów redakcji Szczepańskiego i następnie Górskiego na łamach pisma można było spotkać publicystykę Zofii Daszyńskiej ${ }^{66}$, Anny Wyczółkowskiej ${ }^{67}$, Izabeli Moszczeńskiej ${ }^{68}$, Felicji Nossig ${ }^{69}$, Arvède Barine ${ }^{70}$, a także Marii Szeligi, współtwórczyni międzynarodowego ruchu emancypacyjnego kobiet. W artykule Prąd feministyczny Szeliga wyjaśniała cele ruchu: uzyskanie przez kobiety prawa do swobodnego wyboru kariery zawodowej, prawa do niezależności ekonomicznej oraz prawa wyborczego. Podkreśliła, że prócz dążenia do wprowadzenia koniecznych regulacji prawnych kobiety w szerszym niż dotąd zakresie powinny uczestniczyć w życiu społecznym, wysuwać propozycje dotyczące wychowania, etyki, podziału pracy, zdrowia moralnego i fizycznego ${ }^{71}$.

Zawężenie profilu pisma przez Przybyszewskiego przyczyniło się do uszczuplenia grona współpracowników, między innymi przestały się ukazywać teksty wspomnianych publicystek; jednocześnie pojawiły się nowe autorki:

${ }^{64}$ Zob. P. Cingolani, Tarde : fictions et fragments du XXIe siècle, Variations: http://variations. revues.org/642 [dostęp: 20.07.2015].

${ }^{65}$ Zob. M. Jazownik, Kobiety autorki...

${ }^{66}$ Zob. np. Z. Daszyńska, Nauka poza uniwersytetem, „Życie” 1898, nr 1, s. 2; taż, W kwestii „Wykładów naukowych”, „Życie” 1898, nr 4, s. 38.

${ }^{67}$ Zob. np. A. Wyczółkowska, Uniwersytet kobiecy w Krakowie?, „Życie” 1898, nr 3, s. 25-26.

${ }^{68}$ Zob. np. I. Moszczeńska, Patriotyzm..., dz. cyt.

${ }^{69}$ F. Nossig, Z Paryża (Nowe dzieło Zoli), „Życie” 1897, nr 6, s. 10-11.

${ }^{70}$ A. Barine [właśc. Louise-Cécile Bouffé], Matżeństwo w niebezpieczeństwie. Skargi kobiece, „Życie” 1898, nr 20, s. 231-232.

${ }^{71}$ M. Szeliga, Prąd feministyczny, „Życie” 1897, nr 4, s. 9. 
Dagny Przybyszewska, Maria Krzymuska-Iwanowska, Ewa Luskina, Ludwika Jahołkowska-Koszutska. Ich utwory poetyckie i prozatorskie, podporządkowane estetyce „nagiej duszy”, skoncentrowane głównie na ukazywaniu psychologicznych głębi i zawikłań relacji mężczyzna - kobieta, również przynosiły wizerunek kobiety odległy od ówczesnego stereotypu, akcentującego role matki i żony.

\section{Zagrożenia związane z rozwojem kultury masowej i upowszechnianiem się światopoglądu filisterskiego}

Zagrożenia tego rodzaju nie były tak silnie akcentowane, jak niebawem będzie to miało miejsce na łamach „Chimery” Miriama. Jednak już od pierwszych numerów „Życia” manifestowano obawy przed charakterystyczną dla współczesnej kultury przyziemnością ideałów, zawężeniem horyzontów oraz tendencjami unifikacyjnymi. Artur Górski stwierdzał:

Silna tresura umysłowa w rodzinie i szkołach, a później polityczna w życiu, łamie indywidualności nie podpadające pod ogólny poziom, nie umiejące pogodzić swojej szczerości i bezwzględności umysłowej z dominującymi poglądami ${ }^{72}$.

Wtórował mu Ludwik Szczepański:

żyjemy w epoce mundurów. Mundurki nakłada się już dziesięcioletnim chłopakom, a później nasze wychowanie i życie starają się zrównać umysły strychulcem do jednego poziomu. Militaryzm, biurokracja i potężny prąd reakcyjny wszędzie w Europie występujący z jednej strony - socjalizm drugiej strony, pętają biedną jednostkę, że ledwo tchu zaczerpnąć może $\mathrm{e}^{73}$.

Odpowiedzi na pytanie, jak żyć w świecie opanowanym przez tłum złożony z przeciętnych ludzi, będący wytworem kultury masowej i uwarunkowań społeczno-politycznych, redaktorzy „Życia” poszukiwali między innymi w twórczości Henrika Ibsena. Jego bohaterowie to skrajni indywidualiści, mający na celu przede wszystkim rozwój własnej osobowości, i w związku z tym kierujący się następującymi wskazaniami:

Masz iść drogą prostą ku temu, co jest twoim powołaniem życiowym, celem twego bytu; tym samym masz prawo zrywać i precz odrzucać to, co cię hamuje i więzi,

72 Dr A.G. [Artur Górski], Filozofia u nas, „Życie” 1897, nr 13, s. 2.

${ }^{73}$ L. Szczepański, Sztuka narodowa, „Życie” 1898, nr 10, s. 110. 
a wszystko jedno, czy to będzie twój brat, przyjaciel, nawet żona, choćby własne dziecko lub rodzice. Bo jeśli stłumisz głos wewnętrzny duszy, jeśli zamiast poświęcić mu wszystko, wejdziesz w kompromisy i ustępstwa na rzecz czy to uczuć, czy innych mniejszych obowiązków, tracisz tym samym duszę własnej duszy, cel życia i jego wartość ${ }^{74}$.

Tego rodzaju prawd i zaleceń krytycy związani z „Życiem” nie znajdowali w twórczości na przykład Henryka Sienkiewicza. Antoni Potocki zarzucił bohaterom Bez dogmatu, Rodziny Połanieckich i Quo vadis (Płoszowskiemu, Połanieckiemu i Petroniuszowi) ,sybarytyzm ducha"75, zaś Cezary Jellenta - idąc śladem Wacława Nałkowskiego - uznał przyszłego noblistę za krzewiciela postawy filisterskiej: „Ród Połanieckich - pisał - to apoteoza ograniczoności i poziomych pragnień $[\ldots]^{\prime \prime 76}$.

Na łamach pisma była też krytykowana obyczajowość i pretensjonalna kultura mieszczańska, na przykład w satyrycznym poemacie Tetmajera Pour passer le temps oktawa ${ }^{77}$. Atakowana była ponadto filisterska opinia publiczna, w polemiczno-programowym cyklu Górskiego przyrównana - za Nietzschem - do osła, istoty, która „całą kulturę i całego filistra dźwiga na swoich ramionach”, która „nadaje ton opinii publicznej, wykonuje krytykę, zabiera wszędzie głos decydujący i ma duszę pełną moralności"78. Jednak chyba najbardziej miażdżąca ocena filisterstwa wyszła spod pióra Adolfa Nowaczyńskiego:

Marny filistrów naród nienawidzimy szczerze wszyscy. Ta zwarta, nieskończona falanga czerwonych, twardych karków episjerskich, wychudłych szkap kieratowych, przywiązanych pensją do stołka, a biedą do głupoty, hotelarzy i restauratorów, ekscelencji i aptekarzy, kobiet samic, prowincjonalnych polityków, liberalnych zacofańców, ta falanga, zaczynająca się jezuitą, a kończąca junkrem matołkiem, ta rosnąca milionowa hydra, ta olbrzymia tama zaległa w poprzek rwącego strumienia ludzkiej myśli, ten bierny, ale niepokonany nieprzyjaciel idei i ideałów, nieugięty wróg wolności i piękna, ci Persowie, którzy rządzą Ateny i Ateńczyków, to jest to, co powinno być wygładzone, zniszczone, to co sceptycznie a głośno neguje słowa pisma: na obraz i podobieństwo stworzeni, to co da parafrazować słowa ewangelii i Darwina: z prochu powstałeś, a w małpę się obrócisz ${ }^{79}$.

\footnotetext{
${ }^{74}$ A. Górski, Henryk Ibsen, „Życie” 1898, nr 10, s. 134.

75 A. Potocki, Sylwetki jubileuszowe. Henryk Sienkiewicz, „Życie” 1897, nr 6, s. 2.

${ }^{76}$ C. Jellenta, Dwie epopeje kupieckie, „Życie” 1897, nr 9, s. 2, podkr. autora.

${ }^{77}$ K. Tetmajer, Pour passer le temps oktawa, „Życie” 1897, nr 1, s. 3-4, nr 2, s. 3-4, nr 3, s. 3-4.

${ }^{78}$ Quasimodo [A. Górski], Młoda Polska..., cz. I, „Życie” 1898, nr 15, s. 170. Zob. też: F. Nietzsche, Tako rzecze Zaratustra. Książka dla wszystkich i dla nikogo, przeł. W. Berent, Wydawnictwo Bis, Warszawa 1990, s. 387-388.

${ }^{79}$ A. Nowaczyński, Paul Scheerbart (Sylweta wesolego poety), „Życie” 1898, nr 32, s. 416.
} 
Z lęku przed homogenicznym, bezwzględnym i obłudnym społeczeństwem nasilają się w piśmie postulaty indywidualizmu i szczerości, zwłaszcza w sztuce, postrzeganej jako jedyna przestrzeń wolności, autonomii i autokreacji jednostki ${ }^{80}$. Jako kontrpropozycja wobec światopoglądu filisterskiego na łamach „Życia” wysuwana jest postawa artystowska. Filister okazuje się wspólnym wrogiem wszystkich kolejnych redaktorów „Życia”. W swoich najważniejszych manifestach i artykułach programowych Szczepański, Górski i Przybyszewski mówią w zasadzie jednym głosem o potrzebie autonomii sztuki oraz bronią wolności, szczerości i indywidualności artysty, jedynie rozmaicie rozkładają akcenty $^{81}$.

\section{Możliwości przezwyciężania światopoglądu dekadenckiego i artystowskiego}

Światopoglądy dekadencki i artystowski rychło stały się przedmiotem krytyki ze strony zwłaszcza apologetów romantyzmu. Wspomniany wcześniej kult wieszczów, któremu towarzyszyła rehabilitacja mistycyzmu i towianizmu, ostatecznie na łamach pisma przekształcił się w nurt neomesjanistyczny, związany z propozycją światopoglądową autora Idei polskiej wobec prądów kosmopolitycznych (1897), Stanisława Szczepanowskiego.

Należy zaznaczyć, że idee mesjanistyczne pojawiły się na łamach „Życia” stosunkowo wcześnie. Przedstawiał je bowiem już na początku 1898 roku wspomniany wcześniej Bolesław Lutomski, który pisał:

Wyjątkowe jest w tej epoce położenie społeczeństwa polskiego. Zależne od obcych władców, powinno wytworzyć wewnątrz siebie tyle i takich cnót wewnętrznych, o które by się rozbijały ataki, oszczerstwa i prześladowania nieprzyjaciół. Pierwsze gminy chrześcijańskie dały przykład, jedyny w dziejach powszechnych. Solidarność słabych i biednych wyznawców, przejętych swoją nauką i miłością wzajemną, oparła się naciskowi największej siły świata starożytnego. [...]

Programy polityczne upadają, lecz narody zostają i trwają pod warunkiem, że zrozumieją swoje powołanie w tym wiekuistym toku wypadków, który nazwano ewolucją,

\footnotetext{
${ }^{80}$ Zob. np. B. Wojnowska, Poszukiwanie sacrum w wypowiedziach „Życia” i ,Chimery”, w: Problematyka religijna w literaturze pozytywizmu i Młodej Polski. Świadectwa poszukiwań, red. S. Fita, Towarzystwo Naukowe KUL, Lublin 1993, s. 256-257.

${ }^{81}$ Zob. L. Szczepański, Sztuka narodowa, „Życie” 1898, nr 9, s. 97-98, nr 10, s. 109-110; Quasimodo [A. Górski], Młoda Polska..., „Życie” 1898, nr 15, s. 170-171, nr 16, s. 181-182, nr 18, s. 206 , nr 19 , s. $217-219$, nr 24, s. 278-279, nr 25, s. 299; S. Przybyszewski, Confiteor, „Życie” 1999, nr 1, s. 1-4; tenże, $O$ „,nowa” sztuke, „Życie” 1899, nr 6, s. 102-104.
} 
i wierne dobrym tradycjom historycznym, wytworzą wśród siebie cnoty wewnętrzne, konieczne dla istnienia i rozwoju ${ }^{82}$.

Poglądy neomesjanistyczne ujawniły się zwłaszcza w artykułach Artura Górskiego $^{83}$, Tadeusza Micińskiego ${ }^{84}$, Zygmunta Wasilewskiego ${ }^{85}$, Antoniego Langego $^{86}$, a także w wypowiedzi Karola Baykowskiego ${ }^{87}$. Teksty wymienionych autorów, w większości ogłoszone - co istotne - po publikacji manifestu Stanisława Przybyszewskiego Confiteor ${ }^{88}$, łączy przekonanie, że twórczość artystyczna powinna być podporządkowana realizacji dwóch podstawowych idei społecznych: idei duchowego odrodzenia narodu polskiego (które traktowane jest jako niezbędny warunek odrodzenia politycznego) oraz mesjanistycznej idei posłannictwa narodowego. Wypowiedzi te zawierają zatem zarys pewnej „odrodzeńczej" koncepcji światopoglądowej, którą należy traktować jako swoisty projekt scalenia wartości w zdezintegrowanym świecie człowieka „końca wieku", jako projekt - użyjmy trafnego określenia Wojciecha Gutowskiego - reintegracji, ponownego ,usensowienia” całości świata i podejmowanych w nim ludzkich działań ${ }^{89}$.

\section{Zakończenie}

Lektura roczników „Życia” przekonuje, że redaktorzy i współpracownicy pisma żywo angażowali się w toczące się na przełomie wieków spory ideologiczne i światopoglądowe. Przedmiotem tych sporów były kwestie tworzące swoiste układy antynomiczne, takie jak: obstawanie przy tradycyjnych wartościach - ogłaszanie bankructwa idei, rodzimość - uniwersalizm, swojskość - obcość,

82 B. Lutomski, W chwili przełomu, „Życie” 1898, nr 5, s. 51-52.

${ }^{83}$ A. Górski, Spowiedź poety, „Życie” 1999, nr 4, s. 63-64; tenże, Ton mesjański w duszy Stowackiego, „Życie” 1999, nr 7, s. 131-132.

${ }^{84}$ T. Miciński, O spuściźnie duchowej, „Życie” 1899, nr 7, s. 122; tenże, Słowacki i Calderon w „Księciu niezłomnym”, „Życie” 1999, nr 8, s. 156, 159-161.

${ }^{85}$ Z. Wasilewski, O ton w poezji i w życiu. Z dziejów profesorskich Mickiewicza, „Życie” 1898, nr 25, s. 301-303.

${ }^{86}$ A. Lange, Motyw Juliuszowy, „Życie” 1999, nr 7, s. 130-131.

${ }^{87}$ Towiańszczyk [Karol Baykowski], List otwarty. Do wspótbraci spod zaboru rosyjskiego, „Życie” 1898, nr 36/37, s. 493.

${ }^{88}$ S. Przybyszewski, Confiteor, „Życie” 1999, nr 1, s. 1-4. Warto dodać na marginesie, że w niedalekiej przyszłości propagowaniu mesjanistycznej idei narodowej Przybyszewski poświęci esej Szopen a Naród (1910) oraz swoistą syntezę kultury polskiej, zatytułowaną Szlakiem duszy polskiej (1917).

${ }^{89}$ W. Gutowski, W poszukiwaniu życia nowego. Mit a światopogląd w twórczości Tadeusza Micińskiego, Państwowe Wydawnictwo Naukowe, Warszawa-Poznań-Toruń 1980, s. 8-9. 
tradycja - nowoczesność, wartości filisterskie - wartości dekadenckie i artystowskie. Jak wynika z przedstawionych uwag, publicyści „Życia” zajmowali stanowisko wyrafinowane. Kierując się swoistą dialektyką, uznawali, że wskazane sprzeczności się znoszą. Poszukując dróg wyjścia z kryzysu ideologiczno-światopoglądowego epoki, uważali, że nie należy opowiadać się za którymkolwiek ze skontrastowanych ze sobą stanowisk, ale trzeba dążyć do ich dialektycznego przezwyciężenia. W szczególności nie opowiedzieli się ani za rzecznikami obstawania przy tradycyjnych wartościach, ani też za głosicielami bankructwa wszelkich idei, lecz wybrali trzecią drogą - reintegrację, która pozwalała zachowywać krytyczny dystans wobec tradycyjnej aksjologii, ale też umożliwiała uchronienie się przed chaosem aksjologicznym, albowiem postulowała potrzebę stałego dokonywania przez jednostki świadomych wyborów aksjologicznych i świadomego opowiadania się za wartościami poddawanymi krytycznemu namysłowi.

\section{Bibliografia}

[Górski Artur] ***, Stan wyjątkowy, „Życie” 1898, nr 34, s. 441-442.

[Feldman Wilhelm] $\Delta$, Listy lwowskie, „Życie” 1897, nr 10, s. 6-8; 1898, nr 18, s. 212-213, nr 19, s. 221-223, nr 22, s. 261, nr 26, s. 323-324.

A.G. [Górski Artur], Młodzież a pedagodzy, „Życie” 1898, nr 11, s. 130-131.

Adorno Theodor W., Horkheimer Max, Dialektyka oświecenia. Fragmenty filozoficzne, przekł.

Małgorzata Łukasiewicz, Wydawnictwo Instytutu Filozofii i Socjologii PAN, Warszawa 1994. Audax [Ehrenberg Kazimierz], Uwagi, „Głos Narodu” 1898, nr 248, s. 6, nr 253, s. 5.

Barine Arvède [właśc. Bouffé Louise-Cécile], Małżenstwo w niebezpieczeństwie. Skargi kobiece, „Życie” 1898, nr 20, s. 231-232.

Bąbiak Grzegorz P., Bibliografia zawartości „Życia” warszawskiego i krakowskiego, „, Strumienia” oraz „Chimery”, Wydział Polonistyki UW, Warszawa 2000, s. 41-94.

Boyé Edward, U kolebki modernizmu. Estetyczne poglądy na łamach krakowskiego „Życia”, Krakowska Spółka Wydawnicza, Kraków 1922.

Cingolani Patrick, Tarde: fictions et fragments du XXIe siècle, http://variations.revues.org/642 [dostęp: 20.07.2015].

Czachowska Jadwiga, „Życie” 1897-1900, w: Obraz literatury polskiej XIX i XX wieku, seria V: Literatura okresu Młodej Polski, t. 1, red. K. Wyka, A. Hutnikiewicz, M. Puchalska, PWN, Warszawa 1968, s. 233-244.

Daszyńska Zofia, Nauka poza uniwersytetem, „Życie” 1898, nr 1, s. 2.

Daszyńska Zofia, W kwestii ,Wykładów naukowych”, „Życie” 1898, nr 4, s. 38.

Daszyńska Zofia, Z tajników duszy współczesnej, „Życie” 1898, nr 13, s. 146-147, nr 14, s. 159-160. Dr A.G. [Górski Artur], Filozofia u nas, „Życie” 1897, nr 12, s. 2, nr 13, s. 1-2.

Franko Iwan, Ein Dichter des Verrathes, „Die Zeit” 1897, nr 136, s. 86-89.

Gloger Maciej, Jak czytać pozytywizm. Rekonesans, „Poznańskie Studia Polonistyczne. Seria Literacka" 2000, t. VII: Czytanie pozytywizmu, s. 21-45.

Górski Artur, Henryk Ibsen, „Życie” 1898, nr 10, s. 133-134.

Górski Artur, Jedyny, „Życie” 1899, nr 8, s. 146, 149-151, nr 9, s. 166, 169-173. 
Górski Artur, Spowiedź poety, „Życie” 1999, nr 4, s. 63-64.

Górski Artur, Ton mesjański w duszy Stowackiego, „Życie” 1999, nr 7, s. 131-132.

Górski Artur, Włodzimierz Tetmajer (,Żeńcy”, „Racławice”, „Kantyczki”), „Życie” 1899, nr 13/14, s. 244-245.

[Górski Artur], Do młodzieży, „Życie” 1897, nr 12, s. 1.

Gutowski Wojciech, Stowo wstęne; tenże, Młodopolskie poszukiwania. Ryty odrodzenia, w: tenże, W poszukiwaniu życia nowego. Mit a światopogląd w twórczości Tadeusza Micińskiego, PWN, Warszawa-Poznań-Toruń 1980, s. 5-27.

Jazownik Maria, Fryderyk Chopin w eseistyce Stanisława Przybyszewskiego, w: Słowo, dźwięk, obraz, red. Elżbieta Skorupska-Raczyńska, Joanna Rutkowska, Wydawnictwo Naukowe Państwowej Wyższej Szkoły Zawodowej im. Jakuba z Paradyża w Gorzowie Wielkopolskim, Gorzów Wielkopolski 2016, s. 37-59.

Jazownik Maria, Kobiety autorki w krakowskim „Życiu”, w: Współczesny i dawny obraz kobiety w języku i literaturze, red. L. Mariak, J. Rychter, Volumina.pl Daniel Krzanowski, Szczecin 2015, s. 87-106.

Jazownik Maria, Krakowskie „Życie” wobec setnej rocznicy urodzin Adama Mickiewicza, w: Adam Mickiewicz w kontekstach kulturowych dawnych $i$ współczesnych, red. I. Jokiel, M. Burzka-Janik, Wydawnictwo Uniwersytetu Opolskiego, Opole 2012, s. 200-225.

Jazownik Maria, Krytyka literacka Artura Górskiego 1890-1918, Księgarnia Akademicka, Zielona Góra 2012, s. 64-66, 70-113, 122-134, 204-213.

Jazownik Maria, Obraz Lwowa w korespondencji Wilhelma Feldmana ukazujacej się na tamach krakowskiego „Życia”, w: Dziedzictwo kulturowe regionu pogranicza, t. 6, red. E. Skorupska-Raczyńska, J. Rutkowska, Wydawnictwo Naukowe Państwowej Wyższej Szkoły Zawodowej im. Jakuba z Paradyża w Gorzowie Wielkopolskim, Gorzów Wielkopolski 2015, s. 37-61.

Jazownik Maria, Portret Juliusza Stowackiego na łamach krakowskiego „Życia”. Przyczynek do badań nad stylami lektury wieszcza, w: Współczesne problemy badań nad recepcja oraz oddziaływaniem utworów literackich, red. L. Jazownik, Księgarnia Akademicka, Zielona Góra 2013, s. 149-169.

Jellenta Cezary, Dwie epopeje kupieckie, „Życie” 1897, nr 7, s. 3-4, nr 8, s. 1-2, nr 9, s. 1-2.

Jellenta Cezary, Proces moralny, „Życie” 1898, nr 40/41, s. 522-523, nr 42, s. 549, nr 44, s. 578, nr 45, s. 600, nr 46, s. 607-608.

Kelles-Krauz Kazimierz, Podziemna przyszłość ludzkości, „Życie” 1897, nr 9, s. 5-6, nr 10, s. 4-5, nr 11, s. 5-6, nr 12, s. 5-7, nr 13, s. 5-7, nr 14, s. 6-8; 1898, nr 1, s. 5-7, nr 2, s. 15-17.

Kierkegaard Søren, Dziennik uwodziciela, „Życie” 1899, nr 8, s. 152-155, nr 9, s. 174-175, nr 10, s. 201 , nr 11, s. 219-221, nr 13/14, s. 261-269, nr 15/16, s. 294, 297-300, nr 17/18, s. 339-348, nr 19/20, s. 373-378, nr 21/22, s. 404-410.

Kieżuń Anna, Drogi własne. O twórczości młodopolskiej Artura Górskiego, Wydawnictwo Uniwersytetu w Białymstoku, Białystok 2006, s. 84-120.

Kronika, „Życie” 1898, nr 4, s. 46.

Lange Antoni, Motyw Juliuszowy, „Życie” 1999, nr 7, s. 130-131.

Lutomski Bolesław, W chwili przełomu, „Życie” 1898, nr 5, s. 51-52.

Lutomski Bolesław, Z psychologii narodowej, „Życie” 1897, nr 4, s. 1-2.

Markiewicz Henryk, Dialektyka pozytywizmu polskiego, w: tenże, Przekroje i zblizenia dawne i nowe. Rozprawy i szkice z wiedzy o literaturze, Państwowy Instytut Wydawniczy, Warszawa 1976, s. 20-41. 
Miciński Tadeusz, O spuściźnie duchowej, „Życie”1899, nr 7, s. 122.

Miciński Tadeusz, Słowacki i Calderon w „Xięciu niezłomnym”, „Życie” 1999, nr 8, s. 156, 159161.

Moraczewski Wacław, Wasyl Stefanyk, „Życie” 1899, nr 10, s. 195-196.

Moszczeńska Izabela, Patriotyzm i moralność u nas, „Życie” 1898, nr 15, s. 170-171, nr 16, s. 184-185, nr 17, s. 194.

Nietzsche Friedrich, Z „Also Sprach Zarathustra”, „Życie” 1899, nr 1, s. 17-18.

Nietzsche Friedrich, Jeszcze raz po wszystka wieczność, przekł. J. Żuławski, „Życie” 1900, nr 1, s. 26.

Nietzsche Friedrich, Pieśń nocy, „Życie” 1898, nr 36/37, s. 488.

Nietzsche Friedrich, Przedmowa Zarathustry, „Życie” 1898, nr 47, s. 622, 625, nr 48, s. 639-640, 643.

Nietzsche Friedrich, Tako rzecze Zaratustra. Książka dla wszystkich i dla nikogo, przekł. Wacław Berent, Wydawnictwo Bis, Warszawa 1990, s. 387-388.

Nossig Felicja, Z Paryża (Nowe dzieło Zoli), „Życie” 1897, nr 6, s. 10-11.

Nowaczyński Adolf, Paul Scheerbart (Sylweta wesolego poety), „Życie” 1898, nr 31, s. 400-404, nr 32, s. 415-416.

Partacz Czesław, Od Badeniego do Potockiego. Stosunki polsko-ukraińskie w Galicji w latach 1888-1908, Wydawnictwo Adam Marszałek, Torun 1997.

Podraza-Kwiatkowska Maria, Wstęp, w: Programy i dyskusje literackie okresu Młodej Polski, oprac. M. Podraza-Kwiatkowska, wyd. 3 przejrz. i uzup., Zakład Narodowy im. Ossolińskich, Wrocław 2000, BN I 212, s. V-LXXXII.

Potocki Antoni, Sylwetki jubileuszowe. Henryk Sienkiewicz, „Życie” 1897, nr 2, s. 2, 4, nr 3, s. 2-3, nr 4, s. 2-4, nr 5, s. 1-3, nr 6, s. 1-2.

Potocki Antoni, Totstoj, „Życie” 1898, nr 34, s. 443.

Przybyszewski Stanisław, Apostrofa do Króla Ducha. U progu nowego stulecia, „Życie” 1900, nr 1, s. 3-5.

Przybyszewski Stanisław, Confiteor, „Życie” 1999, nr 1, s. 1-4.

Przybyszewski Stanisław, Ku czci mistrza, „Życie” 1899, nr 19/20, s. 351-356.

Przybyszewski Stanisław, O „nowa” sztukę, „Życie” 1899, nr 6, s. 102-104.

Quasimodo [Górski Artur], Młoda Polska. Fejleton nie posłany na konkurs ,Słowa Polskiego”, „Życie” 1898, nr 15, s. 170-171, nr 16, s. 181-182, nr 18, s. 206, nr 19, s. 217-219, nr 24, s. 278-279, nr 25, s. 299.

Redakcja „Życia”, „Głosowi Narodu” na dalsza droge, „Życie” 1897, nr 3, s. 12.

[Redakcja], J'accuse!, „Życie” 1898, nr 4, s. 37.

Soboń Marcin, Pogromy w Galicji w 1898 roku i ich społeczne konsekwencje, w: tenże, Polacy wobec Żydów w Galicji doby autonomicznej w latach 1868-1914, Wydawnictwo Verso, Kraków 2011, s. 238-270.

Sova Antonín, Teodorowi Mommsenowi, przekł. Maciej Szukiewicz, „Życie” 1897, nr 12, s. 2.

Stala Marian, Człowiek z właściwościami (W kręgu antropologicznej problematyki Młodej Polski), w: Stulecie Młodej Polski. Studia, red. M. Podraza-Kwiatkowska, Universitas, Kraków 1995, s. 135-152.

Szczepański Ludwik, Sztuka narodowa, „Życie” 1898, nr 9, s. 97-98; nr 10, s. 109-110.

Szeliga Maria, Prąd feministyczny, „Życie” 1897, nr 3, s. 5-7, nr 4, s. 8-9.

Szymankiewicz Aleksander, Z historii modernizmu polskiego (, Życie” warszawskie, „Życie” krakowskie, „Chimera”), „Przegląd Humanistyczny” 1923, t. 2, s. 29-55. 
Tatarkiewicz Władysław, Renan i sceptycyzm $w$ pozytywizmie, w: tenże, Historia filozofii, t. 3, PWN, Warszawa 1981, s. 125-130.

Tetmajer Kazimierz, Pour passer le temps oktawa, „Życie” 1897, nr 1, s. 3-4, nr 2, s. 3-4, nr 3, s. 3-4. Tetmajer Włodzimierz, Chłop polski na uroczystości Mickiewiczowskiej, „Życie” 1898, nr 26, s. 313-316. Tołstoj Lew, Co to jest sztuka?, przekł. Antoni Potocki, „Życie” 1898, nr 35, s. 457-459, nr 36/37, s. $476-477$.

Towiańszczyk [Baykowski Karol], List otwarty. Do współbraci spod zaboru rosyjskiego, „Życie” 1898, nr 36/37, s. 493.

W.F. [Feldman Wilhelm], Nietzsche, „Życie” 1898, nr 21, s. 244-245.

Walas Teresa, Ku otchłani (dekadentyzm w literaturze polskiej 1890-1905), Wydawnictwo Literackie, Kraków 1986.

Wasilewski Zygmunt, $O$ ton $w$ poezji $i$ w życiu. Z dziejów profesorskich Mickiewicza, „Życie” 1898, nr 25, s. 301-303.

Weiss Tomasz, Przełom antypozytywistyczny w Polsce w latach 1880-1890 (przemiany postaw światopogladowych i teorii artystycznych), Uniwersytet Jagielloński - PWN, Kraków 1966.

Wilde Oscar, Krytyk jako artysta, przekł. R.W., „Życie” 1898, nr 7, s. 76-77, nr 8, s. 87-88, nr 10, s. 113-114, nr 12, s. 138, nr 13, s. 150-151, nr 16, s. 185-186, nr 17, s. 197, nr 20, s. 233-234.

Wojnowska Bożena, ,,Ruskinizm”w Młodej Polsce, „Studia Estetyczne” 1976, s. 259-281.

Wojnowska Bożena, ,Życie” (1897-1900), w: Stownik literatury polskiej XX wieku, red. A. Brodzka, M. Puchalska, M. Semczuk, A. Sobolewska, E. Szary-Matywiecka, Zakład Narodowy im. Ossolińskich, Wrocław 1992, s. 1239-1244.

Wojnowska Bożena, Poszukiwanie sacrum w wypowiedziach „Życia” $i$ „Chimery”, w: Problematyka religijna $w$ literaturze pozytywizmu i Młodej Polski. Świadectwa poszukiwań, red. S. Fita, Towarzystwo Naukowe KUL, Lublin 1993, s. 253-261.

Wyczółkowska Anna, Uniwersytet kobiecy w Krakowie?, „Życie” 1898, nr 3, s. 25-26.

Wyka Kazimierz, Młoda Polska, t. 1: Modernizm polski. Struktura i rozwój, wyd. 2, Wydawnictwo Literackie, Kraków 1987.

Wyka Kazimierz, Programy, syntezy i polemiki literackie okresu, w: tenże, Młoda Polska, t. 2: Szkice z problematyki epoki, wyd. 2, Wydawnictwo Literackie, Kraków 1987, s. 93-99.

Zimand Roman, ,Dekadentyzm” warszawski, Państwowy Instytut Wydawniczy, Warszawa 1964. Zyga Aleksander, Program ideowo-artystyczny „Życia” za redakcji Ludwika Szczepańskiego, „Ruch Literacki” 1972, z. 3 (72), s. 135-152.

„Życie” (Prospekt), Kraków-Lwów, wrzesień 1897.

Maria Jazownik

\section{Kraków's "Życie” as a forum for presenting ideological trends and philosophical concepts of early modernism (selected problems)}

\section{(Summary)}

The paper presents an overview of Kraków's “Życie” (1897-1900) as a journal that featured the most important ideological and philosophical trends of the late nineteenth century. Examination of journalistic texts on cultural, social and political issue, published in the journal especially 
when Ludwik Szczepanski and Artur Gorski where editors-in-chief, helped to isolate major fields covered in the periodical. These include: (1) bankruptcy of the ideals of the nineteenth century; (2) antinomy of native and universal values as well as values of other cultures; (3) relationship between tradition and modernity; (4) risks associated with the development of mass culture and the dissemination of the philistine worldview; (5) possibilities of overcoming the decadent and artistic worldview. Analysis of journalistic texts devoted to the issues listed above adds to Kraków's "Życie" being characterised as a journal showing the complexity or even - in a sense - the dialectic nature of Polish modernism.

Słowa kluczowe: idee i światopoglądy wczesnego modernizmu; prasa Młodej Polski; „Życie” krakowskie (1897-1900); publicystyka kulturalna, społeczna i polityczna

Keywords: ideas and worldviews of early modernism; press of the Young Poland; Kraków's “Życie" (1897-1900); cultural, social and political journalism 